\author{
Marzena Chrobak (D) \\ Uniwersytet Jagielloński w Krakowie \\ marzena.chrobak@uj.edu.pl
}

\title{
Komunikacja językowa w osiemnastowiecznych francuskich wyprawach naukowych do Laponii, Peru i Afryki Południowej
}

\section{Wprowadzenie}

Dzieje przekładu ustnego obejmują kilka tysięcy lat, lecz historia przekładu ustnego to stosunkowo młoda i peryferyjna subdyscyplina przekładoznawstwa. Dopiero od niedawna badacze mają możliwość wglądu w materiał dźwiękowy zarejestrowany na różnych nośnikach; w odniesieniu do dawnych epok praca historyka polega na analizie pisemnego opisu wypowiedzi ustnych i tropieniu zniekształconego echa dawno wybrzmiałych słów. W tej mozolnie pisanej historii zagadnienie przekładu ustnego w podróżach międzynarodowych zajmuje jak dotychczas niewiele miejsca. Niniejszy artykuł stanowi próbę poszerzenia wiedzy w tym zakresie. Jest to zarazem kontynuacja moich badań w tym obszarze, obejmujących przekład ustny i inne formy komunikacji międzyjęzykowej w wyprawach wojennych, handlowych, misyjnych, turystycznych i odkrywczych w średniowieczu oraz przekład ustny w europejskich wyprawach odkrywczych 
i zdobywczych na terytorium obu Ameryk do połowy XVI wieku¹. Należy przy tym zauważyć, że wyprawy naukowe różnią się od wyżej wymienionych. Ich celem jest zgromadzenie wiedzy z różnych dziedzin poprzez badania, pomiary, obserwacje, ale też w drodze wywiadu. Oprócz komunikacji w sprawach związanych z logistyką wyprawy (orientacja w terenie, kwaterunek, aprowizacja, bezpieczeństwo itp.) dużą wagę odgrywa precyzyjne, wierne, pełne, rzetelne thumaczenie udzielanych przez respondentów informacji na temat danej społeczności i świata, w którym żyje.

Wiek XVIII był dla Europejczyków wiekiem wypraw odkrywczo-naukowych. Na morzach poszukiwano Przejścia Północno-Zachodniego z Atlantyku na Pacyfik, mitycznej Terra Australis, lepszych szlaków żeglugowych. Wypełniano białe plamy, doskonalono mapy lądów i oceanów. Testowano instrumenty, urządzenia, metody badań. Aby ustalić kształt Ziemi - kula czy elipsoida spłaszczona na biegunach? - co pozwoliłoby doświadczalnie dowieść prawdziwości lub fałszywości prawa powszechnego ciążenia sformułowanego przez Isaaca Newtona, francuscy naukowcy zmierzyli trzy stopnie szerokości geograficznej w pobliżu równika - Louis Godin, Pierre Bouguer, Charles-Marie de la Condamine w Peru, 1735-1743 - i jeden stopień w pobliżu bieguna północnego Pierre Louis Maupertuis w Laponii, 1736-1737. Zapowiedź tranzytu Wenus (przejścia Wenus na tle tarczy Słońca) w latach 1761 i 1769, którego obserwacja umożliwiłaby dokładny pomiar odległości naszego globu od Słońca, zmobilizowała wspólnotę naukową całej Europy. Świadomi, że zjawisko najlepiej będzie widoczne z innych kontynentów, naukowcy wyprawili się, mimo wojny siedmioletniej (pierwszej wojny światowej!), w najodleglejsze zakątki Ziemi, przeprowadzając pomiary w około sześćdziesięciu lokalizacjach. Francuska Królewska Akademia Nauk wysłała w roku 1761 trzy ekspedycje astronomiczne: Jean Chappe d'Auteroche udał się na Syberię, Guillaume Le Gentil de la Galaisière do Pondichéry, Alexandre Guy Pingré na wyspę Rodrigues na Oceanie Indyjskim; w 1769 roku Chappe d'Auteroche popłynął na półwysep Baja California, a Pingré - na Haiti ${ }^{2}$. Z pierwszego francuskiego rejsu dookoła świata w latach 1766-1769 Louis Antoine de Bougainville przywiózł opis Tahiti, mapę archipelagów mórz południowych, udoskonaloną metodę obliczania

\footnotetext{
1 Chrobak [2010, 2012].

2 Moureau [1990: 10].
} 
długości geograficznej ${ }^{3}$. Choć kolejny rejs dookoła świata, pod komendą Jean-François de La Pérouse'a, 1785-1788, zakończył się tragicznie, ocalał jego imponujący dorobek naukowy. W Afryce Północnej Jean-André Peyssonnel badał koral w roku 1724, a w Afryce Południowej François Le Vaillant w latach 1781-1784 - ptaki, owady i ssaki. W wieńczącej XVIII wiek wyprawie generała Bonapartego i jego następców do Egiptu w latach 1798-1801 wzięło udział 167 naukowców, inżynierów i artystów, a jej plon naukowy to 25 tomów opisu ziemi faraonów i mameluków ${ }^{4}$.

Podczas każdej wyprawy miała miejsce, mniej czy bardziej udana, komunikacja międzyjęzykowa i międzykulturowa, lecz autorzy relacji zachowują zwykle powściągliwość w jej opisie. Pośrednikom, okolicznościom i problemom aktu komunikacyjnego poświęcają zaledwie wzmianki. Na podstawie takich wzmianek w relacjach Maupertuisa, La Condamine'a i Le Vaillanta postaram się naszkicować obraz komunikacji międzyjęzykowej w trakcie ekspedycji do Laponii, do Peru i do Afryki Południowej. Moja metoda obejmuje sporządzenie korpusu wzmianek, ich hermeneutyczną lekturę, próbę odpowiedzi na klasyczne pytania historyków przekładu: kto tłumaczył, gdzie, kiedy, dla kogo, jak, w jakim celu, z jakim skutkiem $^{5}$, wreszcie syntetyczne przedstawienie wyników ${ }^{6}$. Rozpatruję relacje znane, publikowane w języku francuskim i tłumaczone na języki obce, jednakże - o ile mi wiadomo - nieprzebadane wcześniej pod kątem przekładu ustnego i innych form komunikacji międzyjęzykowej.

\section{Laponia}

Pierre Louis Maupertuis, kierownik ekspedycji mającej na celu zmierzenie jednego stopnia południka na szerokości $68^{\circ} \mathrm{N}$, w Laponii, najdalej wysuniętej na północ części Finlandii, należącej wówczas do Królestwa Szwecji, miał dużo szczęścia. Jego asystentem został Szwed Anders Celsius, zdolny matematyk, fizyk i astronom, wykładowca na uniwersytecie w Uppsali, przebywający w latach 1734-1735 w Paryżu w ramach programu zwiedzania wiodących europejskich obserwatoriów astronomicznych,

3 Taillemite [2006: 102-104]. Przed Bougainville'em świat opływały francuskie statki handlowe, lecz relacje $\mathrm{z}$ ich rejsów nie są znane.

4 Moureau [1990: 11].

5 Zob. np. Pym [2014/1998: ix-xi, 6].

6 W podobny sposób pracowali historycy przekładu z Uniwersytetu w Barcelonie, por. Martinell Gifre i Cruz Piñol [1996], Martinell Gifre i Erlendsdöttir [2005]. 
orędownik idei zmierzenia południka w Laponii. Oprócz szwedzkiego znał język fiński, władał także francuskim jako językiem wykształconej Europy. Z kolei na miejscu - nad rzeką Tornio - zatrudniono jako tłumacza Andersa Hellanta, absolwenta uniwersytetu w Uppsali, rodowitego Lapończyka, doskonale znającego rejon, władającego lapońskim i fińskim, a ponadto mówiącego płynnie po francusku? ${ }^{7}$. W osobach tych dwóch Skandynawów ekspedycja dysponowała zatem lojalnymi, oddanymi przedsięwzięciu, znającymi warunki lokalne tłumaczami-badaczami. Okazali się użyteczni tak podczas trwających niespełna rok (19 czerwca 1736 - 9 czerwca 1737) prac geodezyjnych, czyli głównego celu wyprawy, jak i w trakcie dodatkowych działań akademików, mających na celu poznanie terenów polarnych i ich mieszkańców. I tak np. w Relation d'un voyage au fond de la Lapponie pour trouver un ancien Monument [Relacja z podróży w głąb Lapponii do starożytnego monumentu] Maupertuis oznajmia wyraźnie: „byłem w tej korzystnej sytuacji, że towarzyszył mi p. Celsius, który łączył z największą wiedzą w zakresie Astronomii głęboką erudycję w zakresie języków północnych, \& który przeprowadził pogłębione studia nad napisami runicznymi $[180]^{8}$ ".

Biegła znajomość lokalnych języków przez Celsiusa pozwoliła francuskiemu akademikowi na regularne odwoływanie się do informacji przekazanych przez lapońskich poganiaczy renów, np. „nasi Lappończycy, zawsze skłonni do fantastycznych opowiastek, uraczyli nas przy tej okazji licznymi historiami ludzi, którzy zostali porwani w powietrze przez te huragany, ze swoimi pulkas [saniami] i renami [...] [182]”.

Warto przy tym zauważyć, że Maupertuis sceptycznie traktował pozyskane od autochtonów informacje z dziedzin innych niż etnografia:

wszyscy Lappończycy zapewniają, że znaki te są bardzo starym napisem zawierającym wielkie sekrety: jakąż jednak wagę można przywiązywać do tego, co wyrokują o starożytnościach ludzie, którzy nie znają swojego wieku, \& którzy najczęściej nie wiedzą, kim była ich matka? [191].

7 Szczegółowy opis ekspedycji oraz jej kontekstu naukowego, por. np. Ilife [1993: 355-386], Pekonen i Vasak [2014]. O Andersie Hellancie pisał też Pekonen [2013: 49-57].

8 Pierre Louis Maupertuis [1768], Relation d'un voyage au fond de la Lapponie pour trouver un ancien Monument, [w:] Oeuvres de M. Maupertuis. Nouvelle édition corrigée \& augmentée. Tome troisième, Lyon, chez Jean-Marie Bruyset, 179-206. Wszystkie cytaty i numery stron pochodzą $z$ tego wydania. Thumaczenie cytatów moje. 
Wiedza Celsiusa w zakresie pisma runicznego pozwoliła na definitywne obalenie hipotezy, że znaki na kamiennym monumencie są runami.

Zaledwie rok po zakończeniu ekspedycji i w tym samym roku co francuski oryginał ukazało się tłumaczenie na język szwedzki raportu naukowego pióra Maupertuisa La figure de la terre [Kształt Ziemi] wykonane przez Andersa Hellanta (Jordens Figur, Sztokholm, 1738).

\section{Peru}

W innej sytuacji znaleźli się uczestnicy wyprawy mającej na celu zmierzenie trzech pierwszych stopni południka w pobliżu równika, w okolicach Quito, obecnie stolicy Ekwadoru, a podówczas miasta na terytorium hiszpańskiej kolonii Wicekrólestwa Peru. Kierownictwo naukowe sprawowało trzech członków Królewskiej Akademii Naukowej: Louis Godin, Pierre Bouguer, Charles-Marie de la Condamine; oprócz nich w skład wyprawy wchodzili botanik, medyk, inżynier, specjalista od przyrządów matematycznych oraz trzech topografów. Ekspedycja trwała ponad siedem lat, w latach 1735-1743. Samo dotarcie z Francji do Quito zabrało akademikom prawie rok; powolna i trudna była też podróż z Guayaquil do Quito głównego instrumentu mierniczego: wielkiego i ciężkiego kwadrantu, wędrującego na grzbiecie muła, przez dżunglę, po mostach linowych. Prace geodezyjne utrudniała rzeźba terenu (strome góry o wysokości ponad 4000 m n.p.m., głębokie wąwozy) oraz niesprzyjające warunki atmosferyczne (niskie temperatury, opady śniegu i deszczu, częste mgły uniemożliwiające dokonywanie obserwacji i pomiarów), czynnik ludzki (niesnaski między naukowcami, kradzieże sprzętu, np. znaków triangulacyjnych, przez autochtonów), kłopoty finansowe 9 .

Językiem urzędowym w kolonii był hiszpański; władali nim Hiszpanie urodzeni w Ameryce oraz wielu przedstawicieli rdzennej ludności indiańskiej. W swojej kronice wyprawy Journal du voyage fait par ordre du roi, à l'Equateur, servant d'introduction historique à la mesure des trois premiers degrés du méridien [Dziennik podróży odbytej na rozkaz króla, na Równik, służący za wstęp historyczny do pomiaru trzech pierwszych stopni południka], 1751, sporządzonej ,na podstawie dziesięciu tomów

\footnotetext{
$9 \quad$ Szczegółowy opis wyprawy w języku polskim por. Erickson [1959: 465-481], w języku francuskim - Mercier [1969: 327-374].
} 
spisanych własną ręką dzień po dniu" $[\mathrm{XXV}]^{10}$, La Condamine notuje, że w styczniu 1736 roku w Panamie, w oczekiwaniu na statek do Peru, on sam i jego towarzysze zaczynają się uczyć hiszpańskiego [10]. Trzy miesiące później, w Puerto Viejo, pokazują lokalnemu urzędnikowi „francuski paszport Króla, który rekomendował nas cudzoziemskim Gubernatorom miejsc leżących na naszej trasie; przełożyłem mu go tak, jak umiałem, \& od tego momentu podwoił wobec nas względy i atencję" [12]. W dalszej części La Condamine nie czyni już żadnych zastrzeżeń co do swoich kompetencji językowych, a o kontaktach $\mathrm{z}$ autochtonami opowiada, jakby odbywały się bezpośrednio, bez thumacza. A chodzi o kontakty dotyczące różnych dziedzin i rejestrów językowych: rozmowy towarzyskie i oficjalne, negocjacje z indiańskimi i metyskimi przewodnikami, mulnikami, tragarzami, perory i wyjaśnienia składane w licznych procesach sądowych, w które został uwikłany podczas pobytu w Peru, wreszcie pozyskiwanie informacji z zakresu astronomii, geografii, hydrografii, botaniki, zoologii, etnografii itp., co zleciła mu Akademia Nauk. La Condamine musiał konferować z kowalem w sprawie naprawy kwadrantu i zabiegać o życzliwość wicekróla. Swoją hiszpańszczyznę szlifował zapewne w codziennych kontaktach z mieszkańcami kolonii, a przede wszystkim z dwoma peruwiańskimi oficerami marynarki oddelegowanymi przez wicekróla do udziału w wyprawie, później z zaprzyjaźnionym gubernatorem prowincji Pedrem de Maldonado. Sporadycznie trafiali się rozmówcy francuskojęzyczni. La Condamine wspomina najbardziej zaskakujące przypadki, gdy z użytkownikami swego ojczystego języka spotykał się na głuchej prowincji:

Znaleźliśmy w Quito zaledwie garstkę jezuitów niemieckich lub włoskich, którzy znali francuski (b): nikt nie mówił w tym języku w E'len, w czym nie było nic nadzwyczajnego, natomiast owszem, bardzo niezwykłe było to, że wszyscy go rozumieli, a w każdym razie w piśmie. Pan domu miał francuskie książki; i choć nie mówił w tym języku, nauczył go swoje dzieci. Byłem świadkiem, jak jego jedyny syn [...] przełożył $\mathrm{w}$ dwa dni na hiszpański przedmowę memoriałów Akademii Nauk pióra p. de Fontenelle [66].

(b) Byłbym zapomniał o don Juanie de Lujan, [...] który odbył studia w Paryżu, \& którego rozprawę filozoficzną widziałem.

10 Charles-Marie de La Condamine [1751], Journal du voyage fait par ordre du roi, à l'Equateur, servant d'introduction historique à la mesure des trois premiers degrés du méridien, Paris, Imprimerie royale. Wszystkie cytaty i numery stron pochodzą z tego wydania. Tłumaczenie cytatów moje. 
Dotarłem o jedenastej wieczorem do Quinche, gdzie zastałem Doktora, który dopiero co wrócił z trzymilowego wypadu w góry, by wyspowiadać pewnego Indianina: odpoczywał, thumacząc rozdział z Poszukiwania prawdy ojca Mallebranche; szczególne zajęcie jak na proboszcza Indii hiszpańskich [171].

Z lektury Journal du voyage fait [...] à l'Equateur można zatem odnieść wrażenie, że na wybrzeżu Pacyfiku i w Andach, najszybciej i najtrwalej skolonizowanych przez Hiszpanów, komunikacja językowa przebiegała sprawnie. O problemach napomyka La Condamine dopiero w relacji z półrocznego rejsu po Amazonce, Relation abrégée d'un voyage fait dans l'intérieur de l'Amérique méridionale [Skrócona relacja z podróży odbytej w głąb Ameryki południowej], 1745, kiedy płynąc wraz z Pedrem de Maldonado z Borja, osady leżącej w górnym biegu rzeki Marañon, do Para, czyli do ujścia Amazonki, znalazł się na terenach rozdrobnienia plemiennego i językowego.

Gdzieniegdzie w użyciu był, oprócz hiszpańskiego, także język keczua, narzucony przez inkaskich zdobywców Amazonii w XV wieku, który La Condamine nazywa „dawnym peruwiańskim” i którego garść słownictwa opanował: „Znalazłem w Chuchunga osadę z dziesięcioma rodzinami indiańskimi, rządzonymi przez Kacyka, który rozumiał mniej więcej tyle słów hiszpańskich, ile ja rozumiałem z jego języka" [32] ${ }^{11}$.

Jako duże ułatwienie dla podróżnych traktuje upowszechnienie tego języka jako wspólnego przez hiszpańskich misjonarzy, a także upowszechnienie ,języka brazylijskiego" przez misjonarzy portugalskich:

20 sierpnia wyruszyliśmy z Coari nową łodzią \& z nowymi Indianami. Język peruwiański, znany panu Maldonado \& naszym służącym, \& o którym ja także miałem niejakie pojęcie, służył nam do porozumiewania się z Krajowcami we wszystkich Misjach Hiszpańskich, gdzie postarano się uczynić zeń język wspólny. W Sao Paulo i w Tefé mieliśmy Tłumaczy Portugalskich, którzy mówili Językiem brazylijskim, podobnie wprowadzonym we wszystkich Misjach Portugalskich [113].

11 Charles-Marie de La Condamine [1745], Relation abrégée d'un voyage fait dans l'intérieur de l'Amérique méridionale. Depuis la côte de la mer du Sud, jusqu'aux côtes du Brésil \& de la Guiane, en descendant la riviere des Amazones, lue à l'assemblée publique de l'Académie des sciences, le 28. avril 1745. Avec une carte du Maragnon, ou de la riviere des Amazones, levée par le même, Paris, chez la Veuve Pissot. Wszystkie cytaty i numery stron pochodzą z tego wydania. Tłumaczenie cytatów moje. 
Częstokroć jednak ma do czynienia z językami, ,którymi mówi tylko kilka rodzin” [83]. Uczy się niektórych, sporządza glosariusz „,najczęściej używanych słów różnych języków indiańskich" [55], komentuje je, niekiedy z poczuciem wyższości: ,[Język plemienia Yameos] jest nad wyraz trudny, a ich sposób wymawiania jest jeszcze bardziej niezwykły niż język. Mówią, wstrzymując oddech, \& nie wydają z siebie prawie żadnej samogłoski” [66-67]. ,Język Omagua jest za to miękki i łatwy w wymowie” [72].

Wszystkie języki Ameryki Południowej, o których coś niecoś wiem, są bardzo ubogie; $[\ldots]$ we wszystkich brakuje pojęć na wyrażenie idei abstrakcyjnych i uniwersalnych [...]: Czas, trwanie, przestrzeń, byt, substancja, materia, ciało [...]. Nie ma stosownego słowa odpowiadającego dokładnie pojęciom takim jak cnota, sprawiedliwość, wolność, wdzięczność, niewdzięczność [54].

O ile obserwacje natury fonetycznej akademika można uznać za oparte na solidnych podstawach, o tyle uwagi dotyczące leksyki budzą więcej wątpliwości. Pokrywają się one jednak z opiniami wyrażanymi już przez francuskich misjonarzy działających w tej części Ameryki od XVI wieku.

Glosariuszowi „najczęściej używanych słów różnych języków indiańskich" nie przyświeca wyłącznie praktyczny cel; ma on posłużyć do analizy porównawczej, która pozwoli wykreślić szlaki migracji plemion w obrębie kontynentu, a po włączeniu do korpusu leksyki z języków Afryki, Europy i Azji ustalić pochodzenie Amerindian [56].

$\mathrm{Na}$ ostatnim odcinku rejsu, płynąc z Coari do Para, La Condamine i Maldonado znaleźli się wśród Indian, ,z którymi byliśmy w stanie konwersować jedynie na migi lub też za pomocą krótkiego słowniczka, w którym zebrałem różne pytania w ich Języku, a który jednak, niestety, nie zawierał odpowiedzi" [113-114]. Mimo wszystko La Condamine nie omieszkał zebrać od nich informacji dotyczących nazw rzek i konstelacji, trudno jednak nie zauważyć, że opisana powyżej forma wywiadu podważa wiarygodność uzyskanych danych.

W obu relacjach La Condamine'a wyraźnie zauważalne jest dążenie do opanowania języka środowiska, w którym przebywa. Owszem, korzysta on z pośrednictwa przygodnych tłumaczy, o czym dowiadujemy się pośrednio, z dwóch wzmianek dotyczących głównie ich braku: „Musiałem pozbyć się w Jaen dwóch tubylczych służących, którzy mogli byli posłużyć mi za tłumaczy [keczua]” [32]. „W Sao Paulo i w Tefé mieliśmy Tłumaczy Portugalskich, którzy mówili Językiem brazylijskim, lecz nie znajdując ich w Coari [...]" [114]. Korzystanie z pośrednictwa językowego 
La Condamine wydaje się jednak traktować jako ostateczność mogącą doprowadzić do zakłócenia komunikacji naukowej. Sporządzając mapę dorzecza Amazonki, krytykuje, a zarazem usprawiedliwia poprzednika, który „opierając się na wyjaśnieniach Indian, z których trudno jest wyciągnąć myśli jasne i wyraźne, zwłaszcza kiedy trzeba posłużyć się Tłumaczem, przypisuje tym dwóm rzekom bieg różny od prawdziwego" [128].

Opuszczając Amerykę Południową, La Condamine znał już zapewne biegle język hiszpański oraz być może portugalski. Świadczy o tym informacja, że pomagał pewnemu Francuzowi przełożyć opis obyczajów Indian $\mathrm{z}$ regionu Borja $\mathrm{z}$ hiszpańskiego na francuski [57-58], a także uwaga towarzysząca wyjaśnieniu wyboru holenderskiego, a nie portugalskiego statku jako środka powrotu do Francji: „Wypływając z tą [portugalską] flotą, nie mógłbym się wymówić od zatrzymania się na Dworach w Lizbonie i w Madrycie, od których zaznałem takiej przychylności, \& których języki stały mi się znajome" [197] ${ }^{12}$.

Holenderskiemu kapitanowi z kolei obecność Francuza na pokładzie przydała się do negocjacji z francuskim korsarzem z Saint-Malo, który zaatakował ich na wysokości Bretanii; fakt, że La Condamine „odpowiedział na wszystkie jego pytania", uratował załogę i pasażerów przed przymusową przesiadką na szalupę [206].

Jak się wydaje, komunikacja podczas wyprawy geodezyjnej do Peru przebiegła bez większych zakłóceń dzięki zabiegom La Condamine’a mającym na celu opanowanie języka środowiska, w którym pracował, oraz dzięki pomocy Hiszpanów znających francuski.

\section{Afryka Południowa}

François Le Vaillant albo Levaillant (1753-1824), Francuz urodzony i wychowany w Gujanie Holenderskiej, wykształcony w Niemczech i w Alzacji, po trzyletnich studiach ornitologicznych w Paryżu i uzupełnieniu ich w Holandii wyruszył w prywatną wyprawę do Afryki Południowej. Opuszczając Europę, mówił biegle po francusku, holendersku i niemiecku. W latach 1781-1784 eksplorował tereny na północ od Kraju Przylądkowego (holenderskich posiadłości ze stolicą w Kapsztadzie), zamieszkane przez koczownicze ludy zwane przez Europejczyków Hotentotami i Buszmenami. Zamiłowany myśliwy, przywiózł imponującą kolekcję okazów

12 Po powrocie do Francji La Condamine będzie thumaczył z hiszpańskiego pisma peruwiańskich korespondentów na potrzeby paryskiej Akademii Nauk [Safier 2001: 33]. 
różnych gatunków zwierząt, w tym ponad 2000 ptaków, własnoręcznie zabitych i wypchanych, oraz skórę żyrafy; opisał wiele nowych gatunków ptaków, z których kilka nazwano później jego imieniem. Pod koniec XVIII wieku wydał dwie relacje ze swoich podróży: Voyage de M. Le Vaillant dans l'Intérieur de l'Afrique par Le Cap de Bonne Espérance, dans Les années 1783, 84 \& 85 [Podróż p. Le Vaillanta do wnętrza Afryki przez Przylądek Dobrej Nadziei, w latach 1783, 84 \& 85], Paris, Leroy, 1790, 2 tomy; Second voyage dans l'intérieur de l'Afrique, par le Cap de Bonne-Espérance, dans les années 1783, 84 et 85 [Druga podróż do wnętrza Afryki, przez Przylądek Dobrej Nadziei, w latach 1783, 84 \& 85], Paris, H.J. Jansen et Comp., An III (1795), 3 tomy ${ }^{13}$; oraz sześciotomowy atlas ptaków afrykańskich. W późniejszym okresie opublikował pięć kolejnych studiów ornitologicznych.

W pierwszą wyprawę na północny wschód od Kapsztadu wyruszył 18 grudnia 1781. Karawana składała się z dwóch krytych wozów; w jednym jechały kufry, materace, zaprojektowany przez Le Vaillanta sekretarzyk do przechowywania owadów, motyli i innych delikatnych okazów, broń i amunicja, w drugim kuchnia z grillem. Liczyła (wymienione w tej kolejności) „trzydzieści wołów, [...] trzy konie wierzchowe, dziewięć psów, pięciu Hotentotów" [98 ${ }^{14}$; liczba tych ostatnich później stale rosła, dochodząc niekiedy do czterdziestu. Dołączył do nich kogut, żywy budzik, oraz oswojony pawian, degustator nieznanych owoców i warzyw. W swojej barwnej, pełnej szczegółów i plastycznych opisów relacji Le Vaillant często pisze o rozmowach z Hotentotami z Przylądka (służącymi i tropicielami) $\mathrm{w}$ drodze, w obozie, na polowaniu; $\mathrm{z}$ upodobaniem przytacza długie wieczorne gawędy przy ognisku [136, 225]; niestrudzenie zbiera od nich informacje geograficzne, botaniczne, zoologiczne, etnograficzne. Nie informuje, w jakim języku rozmawiali, po holendersku czy - raczej w przylądkowej odmianie hotentockiego. Nauczył się go prawdopodobnie podczas trzymiesięcznego pobytu w zatoce Saldanha i doskonalił podczas wyprawy; swoją dobrą znajomość tego języka potwierdza w relacji z drugiej wyprawy [87, 209]. Zbliżając się do kraju Kafrów (Murzynów z grupy językowej Bantu), szuka ludzi znających ten teren i języki, znajduje

\footnotetext{
13 Komentarz krytycznoliteracki obu relacji, por. Huigen [2009: 77-88].

14 François Le Vaillant [1790], Voyage de M. Le Vaillant dans l'Intérieur de l'Afrique par le Cap de Bonne Espérance, dans les Années 1780, 81, 82, 83, 84 \& 85, Paris, Chez Leroy. Wszystkie cytaty i numery stron pochodzą z tego wydania. Tłumaczenie cytatów moje.
} 
człowieka o imieniu Hans, syna „białego i Hotentotki” [300], lecz z braku zaufania nie decyduje się na podróż pod jego przewodnictwem do najbliższego królestwa. Napięcia między kolonistami a Kaframi zmuszają go do powrotu do Kapsztadu po szesnastu miesiącach podróży.

Podczas drugiej wyprawy, na północny zachód od Kraju Przylądkowego, za rzekę Oranje, Le Vaillant spis inwentarza zaczyna od ludzi: „dziewiętnaście osób, trzynaście psów, [...]" [13] ${ }^{15}$. W projekcie eksploracji terenów zamieszkanych przez plemiona żyjące w niewielkich grupach i mówiące językami różnymi, choć należącymi do tej samej rodziny języków typu mlaskowego, zagadnienie komunikacji wysuwa się na pierwszy plan. Le Vaillant szuka najpierw osób znających język Namaqua. Kluczową postacią staje się wódz jednej z grup Hotentotów Klaas Baster, syn Europejczyka i Hotentotki, bardzo dobrze mówiący po holendersku, znający z dzieciństwa język Dużych Namaqua, a ponadto znany i szanowany przez to plemię $[57,86]$. Le Vaillant nie zgłasza zastrzeżeń do jego pośrednictwa językowego. Jeden raz zauważa, że Baster nie nadąża z przekładem mowy powitalnej wygłaszanej bardzo szybko przez władczynię grupy Małych Namaqua; na szczęście najważniejszy element przemowy, czyli żądanie gorzałki, zostaje poparty przez kobietę „,bardzo wyraźnym gestem, którego nie sposób było pojąć opacznie" [94].

Podróżując po terenach rozdrobnienia językowego, Le Vaillant opracował skuteczną technikę zapewnienia komunikacji: w każdej wiosce/grupie pozyskuje przewodników i tłumaczy znających język kolejnej wioski/grupy. Skutkuje to powstaniem łańcuchów translatorskich:

Trudności w poznawaniu zwyczajów rosły, w miarę jak posuwałem się do przodu. Kabobiqua mieli własny język, który zawierał hotentockie mlaski, ale który rozumieli tylko Koraqua, z kolei język Koraqua rozumieli tylko moi Namaqua. Kiedy wódz grupy chciał coś mi powiedzieć, zwracał się do moich Koraqua; ci tłumaczyli jego słowa na swój język dla Namaqua, a Namaqua tłumaczyli je na użytek Hotentotów z grupy Klaasa Bastera, którzy wykładali mi je w swoim języku [...]. Jeśli chodzi o moich Hotentotów, których nająłem na Przylądku i w koloniach, nie rozumieli nic a nic z żadnego z tych języków [157].

15 François Le Vaillant [1932], Voyage dans le pays des Petits et des Grands Namaquois, [w:] Voyages de F. Le Vaillant dans l'Intérieur de l'Afrique par le Cap de Bonne Espérance, dans les Années 1781-1785, t. 1, Paris, Librairie Plon. Wszystkie cytaty i numery stron pochodzą z tego wydania. Tłumaczenie cytatów moje. 
Tłumacze pełnią też niekiedy funkcję informatorów. W pewnej wiosce Le Vaillant zostaje wybrany na króla, lecz rozważnie oddaje koronę jednemu z lokalnych kandydatów, posiłkując się wiedzą uzyskaną od tłumaczy, którzy ,powiedzieli mi, że najwięcej ludzi popierało Haripę; jakby w natchnieniu, wskazałem Haripę" [146].

Le Vaillant zauważa deficyty kompetencji swoich przygodnych tłumaczy: „,[Poza tym] moi Namaqua słabo rozumieli język koraquaski, tak słabo, że często kłócili się między sobą co do sensu tego, co im mówiono" [157], a ich pośrednictwo podsumowuje trzeźwo i z przekąsem, wprowadzając nieoczekiwane porównanie: „Myśl docierała do mnie z tyloma zniekształceniami co poeci antyku mimo całego geniuszu naszych wybornych tłumaczy" [157]. Sam stara się uczyć przynajmniej podstawowych słów i wyrażeń w lokalnych językach, świadomy, że w ten sposób nie tylko ułatwia sobie komunikację, ale i zaskarbia sympatię interlokutorów: „W każdej chacie, do której wchodziłem, słyszałem: «Tabacana maté» (dajcie mi tytoniu). Odpowiadałem na to: «Deip maté» (dajcie mi mleka)” [115]. „Bernfry nauczył mnie w namaqua: «Neuycé neup maté», a za każdym razem, kiedy powtarzałem to zdanie młodym kobietom, śmiały się do rozpuku" [132].

Z braku tłumacza Le Vaillant ucieka się do komunikacji niewerbalnej. Pod wioską wojowniczych koczowników Huswana (Buszmenów), postrachu okolicznych plemion, na widok uzbrojonych mężczyzn:

W oddaleniu, w jakim się znajdowałem, nie miałem żadnych szans na to, by mnie usłyszano, a zresztą, cóż powiedzieć ludziom, których języka nie znałem? Postanowiłem więc posłużyć się tym, który byli w stanie zrozumieć, i dałem im, a wraz ze mną moja mała drużyna, wszelkie znaki przyjaźni, jakie przyszły nam na myśl w tych okolicznościach. Nie zrozumieli ich ani w ząb i zostałem zmuszony do użycia jedynego języka, jaki był w ich zasięgu, czyli języka prezentów [174].

Wkrótce z grupy wychodzi czarny mężczyzna, podchodzi do Le Vaillanta i zadaje mu pytania po hotentocku; okazuje się, że zna także język holenderski, że był poddanym Kompanii Wschodnioindyjskiej w Kraju Przylądkowym, zdezerterował, dotarł za zwrotnik Koziorożca i został wodzem jednej z grup Buszmenów; tłumaczy dla Le Vaillanta i udziela mu informacji etnograficznych, w tym o sygnalizacji ogniowej.

Innym dowodem kompetencji Le Vaillanta w zakresie komunikacji niewerbalnej jest dbałość o prezencję podczas spotkania z lokalnym władcą. 
W trakcie dwóch ponad rocznych wypraw do afrykańskiego interioru Le Vaillant stara się opanować lokalne języki. Korzysta z usług przygodnych pośredników językowych, zdając sobie jednak sprawę z ograniczeń tego rozwiązania. Co ciekawe, nawet w najodleglejszych zakątkach spotyka osoby władające językami europejskimi: dzieci małżeństw mieszanych, dezerterów z metropolii.

\section{Wnioski}

Podczas krótkiego wyjazdu do Laponii Maupertuis wykorzystał możliwość współpracy z autochtonami godnymi zaufania, o wysokim statusie społecznym i naukowym, kompetentnymi pod względem językowym i merytorycznym. W jego sytuacji było to najlepsze rozwiązanie, jako że ograniczony czas pobytu za granicą uniemożliwia samodzielną naukę języka obcego, zwłaszcza pochodzącego z odległej rodziny językowej. O swoim asystencie i tłumaczu Andersie Celsiusie wyraża się z szacunkiem, poprzedzając jego nazwisko formą grzecznościową 'pan'.

Perspektywa dłuższego pobytu sprzyja nauce języka lokalnego, umożliwiającej pominięcie lub przynajmniej ograniczenie pośrednictwa językowego. La Condamine nauczył się hiszpańskiego, prawdopodobnie opanował podstawy keczua, interesował się językami Indian amazońskich; Le Vaillant nauczył się języka Hotentotów z Kraju Przylądkowego i podstaw języka Namaqua. Podczas krótkich kontaktów z użytkownikami nieznanego sobie języka obaj korzystają z usług przygodnych tłumaczy naturalnych. La Condamine nie podaje ich imion i nie komentuje ich działań. Le Vaillant podaje imiona Metysów i sygnalizuje ograniczone zaufanie do ich kompetencji językowych i uczciwości.

W komunikacji z autochtonami europejscy naukowcy wykorzystali także ich znajomość języków europejskich: urzędowych języków kolonii, czyli hiszpańskiego w Peru i holenderskiego w Afryce Południowej, języka francuskiego jako dobrowolnie nabytego języka międzynarodowej wymiany towarzyskiej, kulturowej, naukowej.

Skąpość i lakoniczność informacji na temat komunikacji językowej przekazanych przez autorów relacji uniemożliwia obiektywną ocenę, na ile komunikacja poszczególnymi metodami okazała się skuteczna. Możemy jednak domniemywać, że zaspokoiła ich potrzeby w stopniu wystarczającym, jako że cel wypraw został osiągnięty, a ich dowódcy i kierownicy naukowi zyskali uznanie i sławę w środowiskach naukowych Europy. 
Wyniki analizy czterech francuskich relacji są skromne, mogą jednak posłużyć jako zalążek szerszego studium tematu. Ich uzupełnienie o badania nad wyprawami naukowymi zorganizowanymi przez inne państwa w wieku XVIII i w innych okresach z pewnością pozwoli na uzyskanie pełniejszego obrazu komunikacji językowej podczas tej ważnej aktywności ludzkiej, jaką jest naukowe poznawanie świata.

\section{Bibliografia}

\section{Analizowane relacje}

Maupertuis, P.L. (1768), Relation d'un voyage au fond de la Lapponie pour trouver un ancien Monument, [w:] Oeuvres de M. Maupertuis. Nouvelle édition corrigée \& augmentée. Tome troisième, Lyon, chez Jean-Marie Bruyset: 179-206.

La Condamine, Ch.-M. de (1745), Relation abrégée d'un voyage fait dans l'intérieur de l'Amérique méridionale. Depuis la côte de la mer du Sud, jusqu'aux côtes du Brésil \& de la Guiane, en descendant la riviere des Amazones, lûe à l'assemblée publique de l'Académie des sciences, le 28. avril 1745. Avec une carte du Maragnon, ou de la riviere des Amazones, levée par le même, Paris, chez la Veuve Pissot, https://doi.org/10.5962/bhl.title.102381.

La Condamine, Ch.-M. de (1751), Journal du voyage fait par ordre du roi, à l'Equateur, servant d'introduction historique à la mesure des trois premiers degrés du méridien, Paris, Imprimerie royale, https://doi.org/10.5962/bhl. title.146645.

Le Vaillant, F. (1790), Voyage de M. Le Vaillant dans l'Intérieur de l'Afrique par le Cap de Bonne Espérance, dans les Années 1780, 81, 82, 83, 84 \& 85, Paris, Chez Leroy, https://doi.org/10.5962/bhl.title.101757.

Le Vaillant, F. (1932), Voyage dans le pays des Petits et des Grands Namaquois, [w:] Voyages de F. Le Vaillant dans l'Intérieur de l'Afrique par le Cap de Bonne Espérance, dans les Années 1781-1785, Paris, Librairie Plon.

\section{Inne}

Chrobak, M. (2010), „Obraz komunikacji językowej w basenie Morza Śródziemnego w wiekach średnich według literatury rycerskiej i pielgrzymiej", Prace Komisji Neofilologicznej PAU, IX: 41-57.

Chrobak, M. (2012), Między światami. Tłumacz ustny oraz komunikacja międzykulturowa w literaturze odkrycia i konkwisty Ameryki, Wydawnictwo Uniwersytetu Jagiellońskiego, Kraków. 
Erickson, R. (1959), „Francuska wyprawa geodezyjna z roku 1735”, Kwartalnik Historii Nauki i Techniki, 4/3: 465-481.

Huigen, S. (2009), „Les aventures d'un Créole du Surinam en Afrique: le récit ethnographique de Français Le Vaillant", [w:] Catherine Gallouet et al., red. L'Afrique et les Africains au siècle des Lumières; Savoirs et représentations, Voltaire Foundation, Oxford: 77-88.

Ilife, R. (1993), „Ce que Newton connut sans sortir de chez lui: Maupertuis et la forme de la terre dans les années 1730", Histoire \& Mesure, 8-3/4: 355-386, https://doi.org/10.3406/hism.1993.1601.

Martinell Gifre, E., Cruz Piñol, M. (red.) (1996), La conciencia lingüistica en Europa. Testimonios de situaciones de convivencia de lenguas (ss. XVII-XVIII), PPU, Barcelona.

Martinell Gifre, E., Erlendsdöttir, E. (red.) (2005), La conciencia lingüistica europea. Nuevas aportaciones de impresiones de viajeros, PPU, Barcelona.

Mercier, R. (1969), „Les Français en Amérique du Sud au XVIIIe siècle: la mission de l'Académie des Sciences (1735-1745)", Revue française d'histoire d'outre-mer, tome 56, no 205: 327-374, https://doi.org/10.3406/outre.1969.1492.

Moureau, F. (1990), „L'oeil expert: voyager, explorer. Présentation”, Dix-huitième siècle. Voyager, explorer, 22: 5-12, https://doi.org/10.3406/dhs.1990.1736.

Pekonen, O. (2013), „The Amateur Astronomer Anders Helland and the Plight of his Observations of the Transits of Venus in Tornio, 1761 and 1769", The Journal of Astronomical Data, 19(1): 49-57.

Pekonen, O., Vasak, A. (2014), Maupertuis en Laponie. À la recherche de la figure de la Terre, Hermann Éditeurs, Paris.

Pym, A. (2014/1998), Method in Translation History, Routledge, New York, https://doi.org/10.4324/9781315760049.

Safier, N. (2001), „Unveiling the Amazon to European Science and Society: The Reading and Reception of La Condamine's Relation abregée d'un Voyage fait dans l'intérieur de l'Amérique méridionale (1745)", Terrae Incognitae. The Journal of the Society for the History of Discoveries, 33(1): 33-47, https://doi. org/10.1179/tin.2001.33.1.33.

Taillemite, É. (red.) (2006), Bougainville et ses compagnons autour du monde 1766-1769, t. 1. Journaux de navigation, Imprimerie nationale Éditions, Paris, éd. 2, „Introduction”. 


\begin{abstract}
Abstrakt
Artykuł stanowi próbę naszkicowania obrazu komunikacji językowej podczas wypraw naukowych poprzez tropienie i analizę wzmianek na ten temat w relacjach kierowników wypraw. Badaniu poddano jedną relację Maupertuisa z wyprawy do Laponii (1734-1735), dwie relacje La Condamine'a z wyprawy do Peru (1735-1743), dwie relacje Le Vaillanta z wypraw po Afryce Południowej (1781-1784). Podczas krótkiego wyjazdu do Laponii Maupertuis wykorzystał możliwość współpracy z naukowcami - szwedzkim i lapońskim - godnymi zaufania, kompetentnymi pod względem językowym i merytorycznym. La Condamine i Le Vaillant starali się uczyć języków lokalnych (hiszpańskiego, keczua; hotentockiego, namaqua), pragnąc wyeliminować pośrednictwo tłumacza. Na terenach rozdrobnienia językowego obaj korzystali z usług przygodnych tłumaczy naturalnych. W komunikacji z autochtonami europejscy naukowcy wykorzystali także ich znajomość języków europejskich: urzędowych języków kolonii, czyli hiszpańskiego w Peru i holenderskiego w Afryce Południowej, oraz języka francuskiego jako dobrowolnie nabytego języka międzynarodowej wymiany towarzyskiej, kulturowej, naukowej.
\end{abstract}

Słowa kluczowe: historia komunikacji językowej, historia przekładu ustnego, francuskie wyprawy naukowe, Maupertuis, La Condamine, Le Vaillant

\title{
Abstract \\ Interlingual Communication during French Scientific Expeditions to Lappland, Peru and South Africa in the 18th Century
}

In this paper, I try to outline the image of the interlingual communication during scientific expeditions by detecting and analysing remarks about such instances in the narratives by the expeditions' commanders. I analyse a narrative of Maupertuis on his geodesic mission to Lappland (17341735), two narratives of La Condamine on his geodesic mission to Peru (1735-1743), and two narratives of Le Vaillant on his travels across South Africa (1781-1784). During his short stay in Lappland, Maupertuis was assisted by a Swedish astronomer and by a Laponian, both speaking French and Finnish. La Condamine and Le Vaillant learned local languages (Spanish, Quechua; Hottentot, Namaqua) in order to eliminate the intermediation of an interpreter. In linguistically fragmented areas, they worked with 
random natural interpreters. French scientists also made use of the native inhabitants' familiarity with European languages: official languages of the colonies (Spanish in Peru, Dutch in South Africa) and French, the language of social, cultural and scientific discourse in the 18th century, which they acquired for pleasure.

Keywords: history of interlingual communication, history of the interpretation, French scientific missions, Maupertuis, La Condamine, Le Vaillant 